\title{
A simple and efficient method for isolating small RNAs from different plant species
}

\author{
Flor de Fátima Rosas-Cárdenas ${ }^{1}$, Noé Durán-Figueroa', Jean-Philippe Vielle-Calzada', Andrés Cruz-Hernández², \\ Nayelli Marsch-Martínez ${ }^{1}$, Stefan de Folter ${ }^{{ }^{*}}$
}

\begin{abstract}
Background: Small RNAs emerged over the last decade as key regulators in diverse biological processes in eukaryotic organisms. To identify and study small RNAs, good and efficient protocols are necessary to isolate them, which sometimes may be challenging due to the composition of specific tissues of certain plant species. Here we describe a simple and efficient method to isolate small RNAs from different plant species.

Results: We developed a simple and efficient method to isolate small RNAs from different plant species by first comparing different total RNA extraction protocols, followed by streamlining the best one, finally resulting in a small RNA extraction method that has no need of first total RNA extraction and is not based on the commercially available TRIzol ${ }^{\circledR}$ Reagent or columns. This small RNA extraction method not only works well for plant tissues with high polysaccharide content, like cactus, agave, banana, and tomato, but also for plant species like Arabidopsis or tobacco. Furthermore, the obtained small RNA samples were successfully used in northern blot assays.

Conclusion: Here we provide a simple and efficient method to isolate small RNAs from different plant species, such as cactus, agave, banana, tomato, Arabidopsis, and tobacco, and the small RNAs from this simplified and low cost method is suitable for downstream handling like northern blot assays.
\end{abstract}

\section{Introduction}

Over the last decade small RNAs (sRNAs) have arisen as key regulators of diverse biological processes in eukaryotic organisms, including for instance development or stress responses, among others (reviewed in: [1-4]). sRNAs are around 20-30 nucleotide (nt) long, and guide regulatory processes at the RNA or DNA level.

The presence of endogenous sRNAs is now reported for many model plants and various non-model species (e.g. $[5,6])$, and elucidating the functions for many of these sRNAs will be a challenge in the near future. Two major classes of sRNAs are microRNAs (miRNAs; 21 and $24 \mathrm{nt}$ long) and small-interfering RNAs (siRNAs; 18-24 nt long), with the latter being the most abundant, though, functionally less understood.

Various protocols are available for sRNA isolation from plants (e.g. [6-14]), though most of them are used

\footnotetext{
* Correspondence: sdfolter@ira.cinvestav.mx

'Laboratorio Nacional de Genómica para la Biodiversidad (LANGEBIO), CINVESTAV-IPN, Km. 9.6 Libramiento Norte, Carretera Irapuato-León, CP 36821 Irapuato, Guanajuato, México

Full list of author information is available at the end of the article
}

for model plant species. Normally, these protocols start with total RNA isolation, followed by the isolation or separation of the low molecular weight RNA species (LMW RNA), containing the sRNAs. The most commonly used protocol is based on the extraction of total RNA using TRIzol ${ }^{\circledR}$ Reagent $[15,16]$ followed by precipitation of LMW RNAs using polyethylene glycol, and finally resulting in RNA species less than $300 \mathrm{nt}$ long. Another protocol for total RNA isolation from tissues with higher contents of polysaccharides is the cetyltrimethylamonium bromide $(\mathrm{CTAB})$ method $[7,8]$. These are useful protocols, but sometimes it is possible that these protocols do not work well for other plants species or specific tissues, or become quite labor-intensive due to difficult handling and the need of extra precipitation steps.

This motivated us to investigate whether it would be possible to find a generic protocol to isolate sRNAs, which would also work for plant tissues with a high polysaccharide content. In this report, a sRNA isolation method is presented that works efficiently for different plant species like cactus, banana and tomato fruits, and

\section{(Ciomed Central}


agave leaves, but also for Arabidopsis and tobacco with less polysaccharide content. The method presented here is not based on the use of the TRIzol ${ }^{\circledR}$ Reagent or commercial columns and omits the total RNA isolation step and, therefore, becomes a simpler and cheaper sRNA isolation method for plants.

\section{Materials and methods}

Plant material

Prickly pear (Opuntia robusta) cactus pads and floral buds were collected at INIFAP (Mexican National Institute of Forestry, Agriculture, and Livestock Research) Campo Experimental Norte de Guanajuato, in San Luis de la Paz, Gto., Mexico. Agave leaves were collected at the campus of CINVESTAV, Irapuato, Gto., Mexico. Arabidopsis thaliana (ecotype Ws-3) and Nicotiana tabacum plants were grown under conventional long day growth conditions $\left(22^{\circ} \mathrm{C}, 16\right.$ hours of light). Banana and tomato fruits were purchased at the local market. The samples were sliced, ground to a fine powder in a mortar with liquid nitrogen and stored at $-80^{\circ} \mathrm{C}$ until further use.

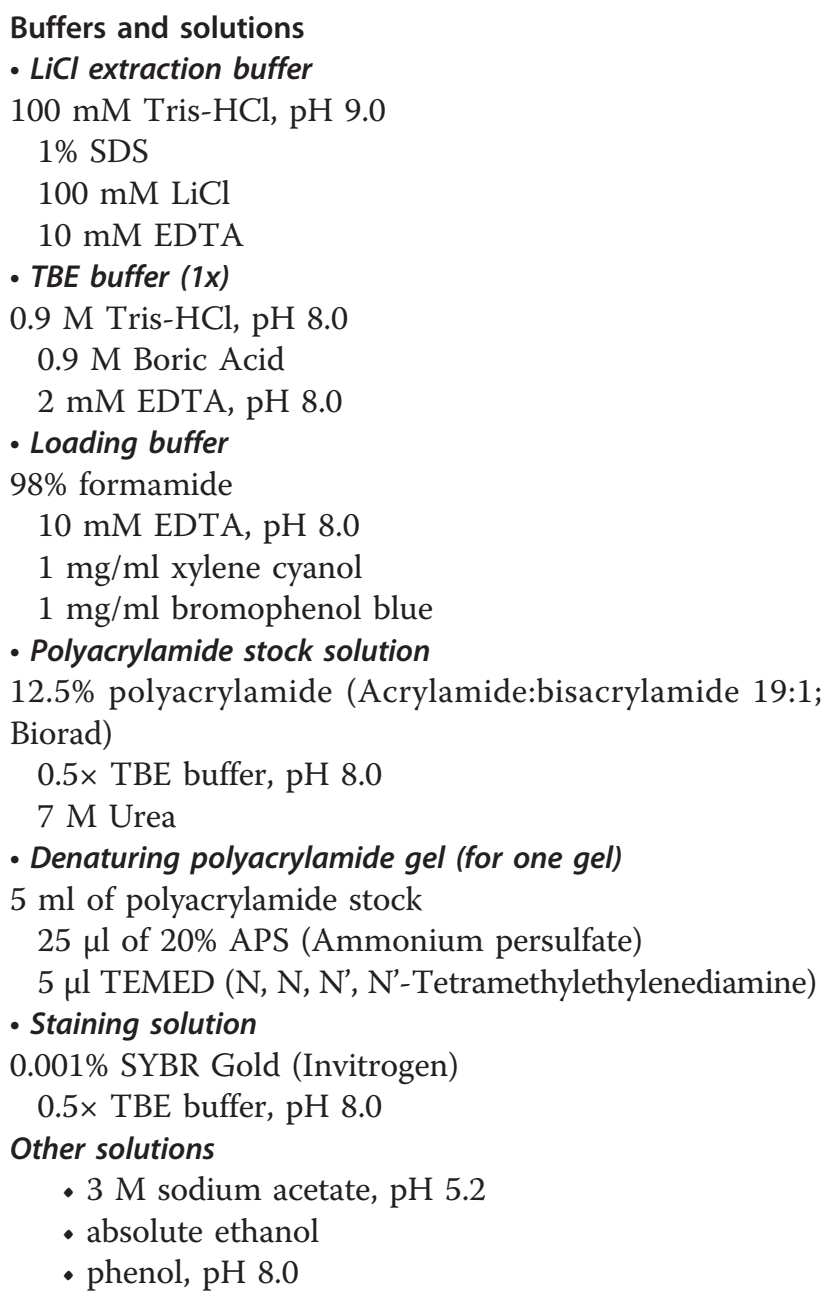

- chloroform-isoamyl alcohol (24:1; v/v)

- phenol-chloroform-isoamyl alcohol (25:24:1; v/v/v)

- $5 \mathrm{M} \mathrm{NaCl}$ solution

- 40\% polyethylene glycol 8000 solution (PEG 8000)

- DEPC treated $(0.05 \%)$ water

\section{For northern blot analysis}

- EDC fixation solution $(24 \mathrm{ml})$

$245 \mu \mathrm{l}$ of $12.5 \mathrm{M}$ methylimidazole, $\mathrm{pH} 8.0$

0.5 g 1-ethyl-3-(3-dimethylaminopropyl) carbodiimide (EDC)

- Hybridization solution (100 ml)

10 g dextran sulphate

$5 \mathrm{ml}$ of $20 \%$ SDS

$20 \mathrm{ml}$ of $5 \mathrm{M} \mathrm{NaCl}$

$5 \mathrm{ml}$ of $1 \mathrm{M}$ Tris- $\mathrm{HCl}, \mathrm{pH} 7.5$

- Wash solution

$2 \times$ SSC

$0.1 \%$ SDS

\section{Protocol}

\section{Small RNA extraction}

1. Place $0.1 \mathrm{~g}$ of pulverized frozen tissue in a $1.5 \mathrm{ml}$ microcentrifuge tube and add $500 \mu \mathrm{l}$ of $\mathrm{LiCl}$ extraction buffer and $500 \mu \mathrm{l}$ of phenol $\mathrm{pH}$ 8.0.

2. Shake or mix well using a vortex for $1 \mathrm{~min}$. Place each sample on ice until all samples are ready.

3. Incubate tubes for $5 \mathrm{~min}$ at $60^{\circ} \mathrm{C}$.

4. Centrifuge for $10 \mathrm{~min}$ in a microcentrifuge at $\max$ speed at $4^{\circ} \mathrm{C}$.

5. Transfer the upper phase to a new microcentrifuge tube and add $600 \mu \mathrm{l}$ of chloroform-isoamyl alcohol (24:1; v/v).

6. Centrifuge $10 \mathrm{~min}$ at $\max$ speed at $4^{\circ} \mathrm{C}$.

7. Transfer the upper phase to a new microcentrifuge tube and incubate for $15 \mathrm{~min}$ at $65^{\circ} \mathrm{C}$.

8. Add $50 \mu \mathrm{l}$ of $5 \mathrm{M} \mathrm{NaCl}$ and $63 \mu \mathrm{l}$ of $40 \%$ polyethylene glycol $8000(\mathrm{w} / \mathrm{v})$ and mix using a vortex for $1 \mathrm{~min}$, followed by incubation on ice for at least $30 \mathrm{~min}$.

9. Centrifuge for $10 \mathrm{~min}$ at $\max$ speed at $4^{\circ} \mathrm{C}$ (Note: the supernatant contains LMW RNA and the pellet consists of HMW RNA and DNA).

10. Transfer supernatant to a new microcentrifuge tube and add $500 \mu \mathrm{l}$ of phenol-chloroform-isoamyl alcohol $(25: 24: 1 ; \mathrm{v} / \mathrm{v} / \mathrm{v})$.

11. Centrifuge for $10 \mathrm{~min}$ at max speed at $4^{\circ} \mathrm{C}$.

12. Transfer supernatant to a new microcentrifuge tube and precipitate LMW RNA by adding $50 \mu \mathrm{l}$ of $3 \mathrm{M}$ sodium acetate pH 5.2 and $1200 \mu \mathrm{l}$ of absolute ethanol.

13. Incubate overnight at $-20^{\circ} \mathrm{C}$.

14. Centrifuge for $10 \mathrm{~min}$ at $\max$ speed at $4^{\circ} \mathrm{C}$.

15. Discard supernatant and dry pellet. When dry, resuspend in $20 \mu \mathrm{l}$ RNAse-free water. 
16. Determine RNA purity and concentration by measuring their absorbance at 230, 260 and $280 \mathrm{~nm}$, and calculate the A260/A280 and A260/A230 ratios.

\section{Small RNA analysis in polyacrylamide gel}

1. Prepare a denaturing $12.5 \%$ polyacrylamide gel by mixing all components (see Materials and Methods; vertical electrophoresis gel system; work RNAse-free). Let the polyacrylamide polymerize for at least $30 \mathrm{~min}$ and then remove combs, gels may be stored at $4{ }^{\circ} \mathrm{C}$. Note: Polymerization time affects the quality of the run, and we have noted that gels prepared two days previous to their use showed improved band definition.

2. Pre-run the gel(s) in $0.5 \times$ TBE buffer (to remove ammonium persulfate residues) for $2 \mathrm{~h}$ at $90 \mathrm{~V}$.

3. Prepare samples. For $2 \mu \mathrm{g}$ LMW RNA, add 0.3 (v/v) loading buffer (adjust to the same volume in all samples with RNAse-free water). Incubate samples for $5 \mathrm{~min}$ at $65^{\circ} \mathrm{C}$ to denature RNA and immediately place on ice for at least for $1 \mathrm{~min}$.

4. Before loading each sample in the gel, wash each gel slot with $0.5 \times$ TBE using a syringe.

5. Load the samples in the gel (fill empty slots with loading buffer) and run for around $2 \mathrm{~h}$ at $90 \mathrm{~V}$ in $0.5 \times$ TBE buffer (until bromophenol blue of the loading buffer reaches the end of the gel).

6. When the electrophoresis run is ready, take the gel out the chamber and stain for $30 \mathrm{~min}$ in $15 \mathrm{ml} 0.5 \times$ TBE buffer with $0.001 \%$ SYBR Gold. Afterwards, rinse for 5 min with RNAse-free water.

7. Visualize the gel under UV light.

\section{Northern blot analysis}

1. The gel may be used for northern blot analysis. In this report, the northern blot analysis was performed following the protocol by Pall and Hamilton (2008) [17] with modifications. Use a semidry trans-blot system (Biorad) to transfer the gel to a neutral nylon membrane (Hybond-NX, GE Healthcare) in 0.5× TBE buffer for $1 \mathrm{~h}$ at $10 \mathrm{~V}$. Air dry the membrane at room temperature, add $12 \mathrm{ml}$ of freshly made EDC fixation solution, incubate the membrane for $30 \mathrm{~min}$ at $60^{\circ} \mathrm{C}$, and then rinse twice with RNAse-free water. Repeat this fixation step once more. Let the membrane dry and store at $-20^{\circ} \mathrm{C}$ till further use.

2. Pre-hybridize with $15 \mathrm{ml}$ hybridization solution (containing denatured salm sperm DNA) for $1.5 \mathrm{~h}$ at $60^{\circ} \mathrm{C}$, followed by replacing the hybridization solution and adding the labelled probe of interest, and incubate for $24 \mathrm{~h}$ at $60^{\circ} \mathrm{C}$. In this report, two probes were used (5'-AGGGGCC ATGCTAATCTTCTC-3' and 5'-AAGAGCT CCCTT CAATCCAAA-3'), each labelled with $[\gamma-32 \mathrm{P}] \mathrm{ATP}$ to detect the small nucleolar RNA U6 and miRNA159a, respectively.
3. Wash the membrane twice with wash solution (first for $4 \mathrm{~min}$, and then a second time for $2 \mathrm{~min}$ ) at room temperature, followed by exposure to a storage phosphor screen for $\sim 48 \mathrm{~h}$ at room temperature.

\section{Comments}

\section{Total RNA isolation}

The isolation of total RNA is a common step prior to LMW RNA isolation. Three different total RNA isolation protocols were compared: TRIzol ${ }^{\circledR}$ (Invitrogen, Carlsbad, CA), CTAB [7], and $\mathrm{LiCl}$ [18]. We performed the comparison using a difficult (regarding RNA isolation) plant species, namely the prickly pear cactus (Opuntia robusta), because there are already many examples of successful total RNA isolation for model plants like Arabidopsis.

Total RNA was isolated from cactus pads and floral buds as shown in Figure 1a. Differences in yield and quality were observed with respect to the tissue type. Total RNA was best isolated from cactus pads using TRIzol $^{\circledR}$ Reagent, while total RNA from floral buds was best isolated using the $\mathrm{LiCl}$ protocol. The 260/280 ratios were similar among the different methods (1.76-2.19), as presented in Table 1 . However, 260/230 ratios showed large variations (0.21-2.03), being especially low when TRIzol $^{\circledR}$ Reagent was used. Possibly, guanidine thyocianate or other contaminants could be producing this effect. Electrophoretic analysis showed that the $\mathrm{LiCl}$ method produced the best RNA quality (Figure 1a). Moreover, this method was easier in comparison with the CTAB and TRIzol ${ }^{\circledR}$ methods, as the mucilage, present in the cactus tissue, greatly difficulted handling and separation of the upper phases, requiring considerably long times for these steps.

\section{Small RNA enrichment}

sRNA enrichment consists in the separation of RNA in high and low molecular weight species (which can be used for further analysis in gels, library construction, or direct sequencing). Besides comparing the different protocols of total RNA extraction for the more difficult cactus plant (Figure 1a), it was also analyzed whether the total RNA isolated using the different extraction methods finally results in a difference in LMW RNA enrichment. For this, total RNA was isolated using the three different extraction methods (TRIzol ${ }^{\circledR}, \mathrm{CTAB}$, and $\mathrm{LiCl}$ ) and enriched for LMW RNA (step 8-15 of small RNA extraction protocol). A positive relationship between the quality and yield of LMW RNA and total RNA obtained by the different methods was observed (Figure $1 \mathrm{~b}$ and Table 1). The supernatant obtained in the $\mathrm{LiCl}$ method was also analyzed, since it is assumed that sRNAs do not co-precipitate well with the HMW RNAs [11]. Indeed, this fraction contained high amounts of LMW 


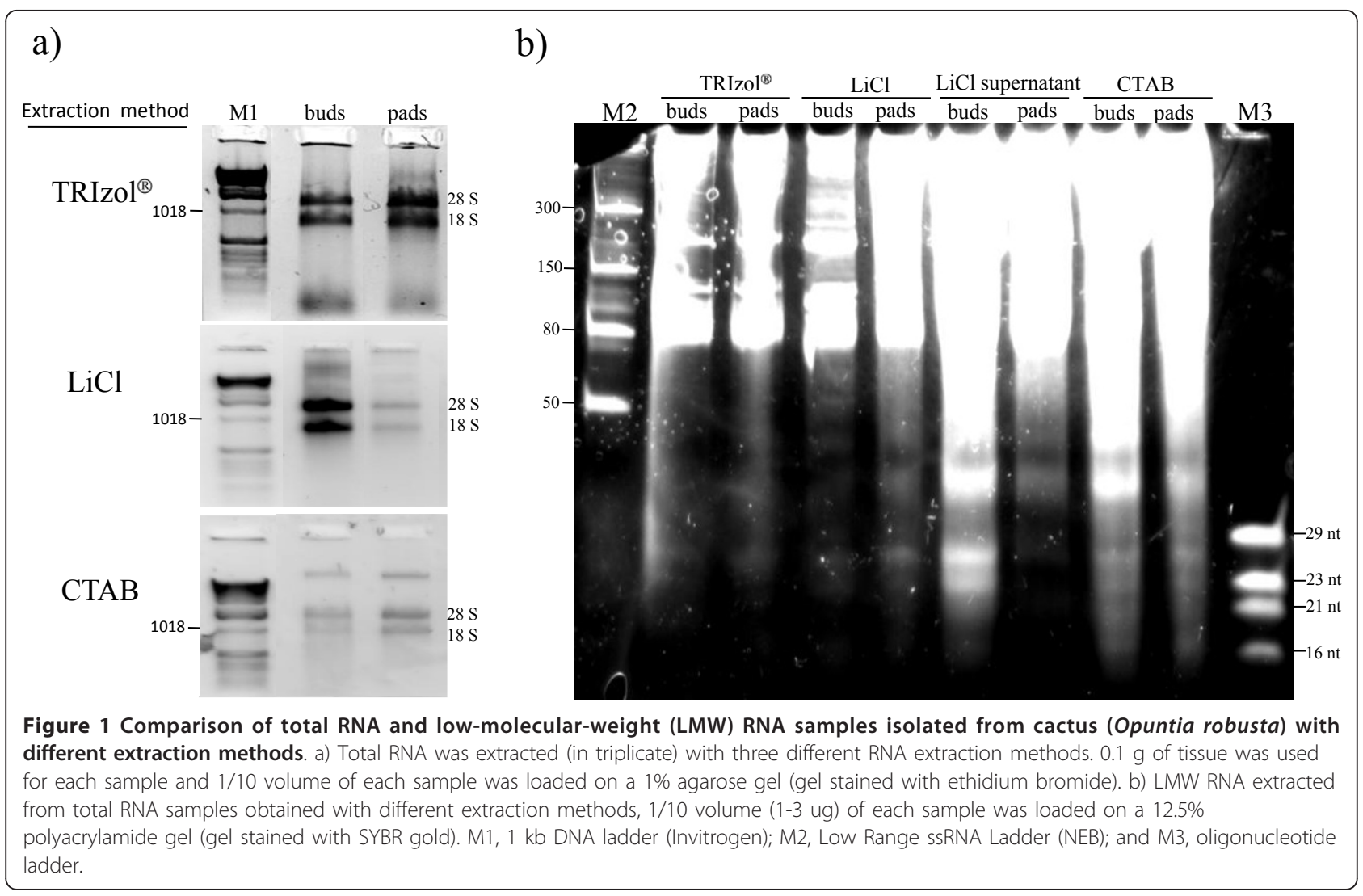

RNAs, especially when isolated from floral buds (as shown in Figure 1b). Both the tissue type and the isolation method contributed to the yield. From the isolation method comparison, it was concluded that LMW RNA from the $\mathrm{LiCl}$ supernatants, and total RNA obtained with the LiCl method showed higher yields and quality.

As sRNAs were obtained both from the supernatant and the total RNA pellet (Figure 1b), it was tested whether the extraction could be streamlined avoiding the total RNA separation step. Different strategies were tested to optimize the extraction protocol in a way that sRNAs could be directly obtained by omitting the $\mathrm{LiCl}$ total RNA precipitation step. For this, the original $\mathrm{LiCl}$ protocol [18] was modified in four different ways by consequentially removing steps (Figure 2). As a control, the modifications were also tested with the model plant Arabidopsis. In the first modification, the enrichment step was performed using the supernatant directly after

Table 1 Concentration* of total RNA and LMW RNA samples obtained using different extraction methods

\begin{tabular}{|c|c|c|c|c|c|c|c|}
\hline Method & Tissue & Average $260 / 280$ & Average $260 / 230$ & total RNA yield $(\mu \mathrm{g})$ & $260 / 280$ & $260 / 230$ & LWM RNA yield $(\mu \mathrm{g})$ \\
\hline \multirow[t]{2}{*}{$\overline{\text { TRIzol }^{\circledR}}$} & buds & 1.84 & 0.21 & 76.3 & 1.96 & 1.73 & 56.34 \\
\hline & pads & 1.83 & 0.25 & 50.28 & 1.96 & 1.59 & 38.4 \\
\hline \multirow[t]{2}{*}{$\mathrm{LiCl}$} & buds & 2.19 & 2.03 & 34.18 & 1.85 & 2.25 & 16.33 \\
\hline & pads & 1.76 & 1.72 & 4.20 & 1.85 & 2.24 & 1.57 \\
\hline \multirow[t]{2}{*}{ LiCl supernant } & buds & - & - & - & 2.03 & 1.94 & 29.88 \\
\hline & pads & - & - & - & 1.87 & 1.61 & 24.42 \\
\hline \multirow[t]{2}{*}{ CTAB } & buds & 2.19 & 2.01 & 24.65 & 2.12 & 2.22 & 16.81 \\
\hline & pads & 1.86 & 1.29 & 17.60 & 2.05 & 2.15 & 10.26 \\
\hline
\end{tabular}

*Yields and spectrophotometric A260/A230 and A260/A280 ratios of total RNA and LMW RNA samples extracted from cactus floral buds and pads with different extraction methods. $1 \mathrm{~g}$ of tissue was used for each total RNA extraction (in triplicate) and quantified in a Nanodrop spectrophotometer, followed by LMW RNA extraction (from 3 pooled total RNA samples). 


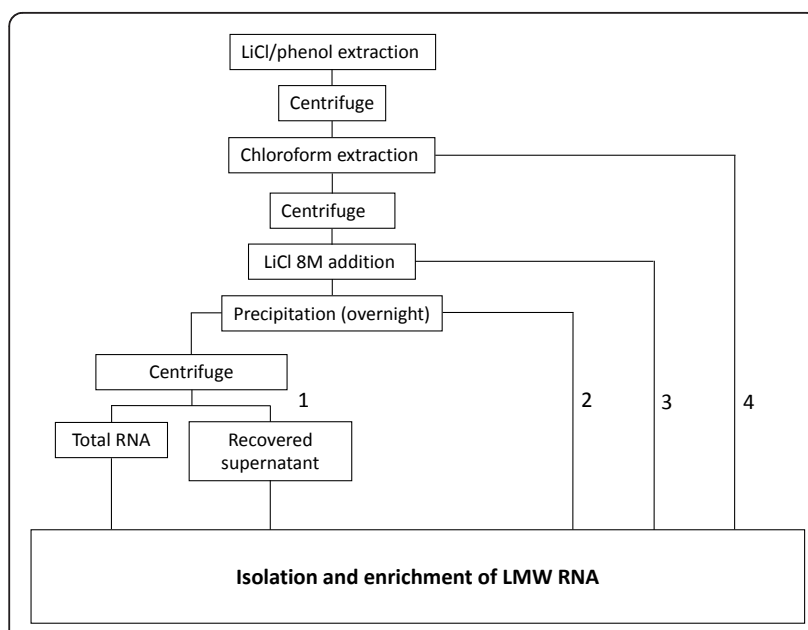

Figure 2 Overview of the $\mathrm{LiCl}$ extraction method modifications. 1) LMW RNA enrichment from the supernatants obtained after precipitation of total RNA, 2) LiCl overnight precipitation, followed by LMW RNA enrichment, 3) LiCl addition, immediately followed by enrichment of LMW RNA, and 4) Enrichment of LMW RNA directly after the chloroform extraction, omitting the $\mathrm{LiCl}$ precipitation step.

total RNA precipitation (without using the pellet containing HMW RNA), which produced positive results (Figure $3 \mathrm{a}$ and $\mathrm{3b}$ ). In the second modification, LMW enrichment was performed directly after the overnight $\mathrm{LiCl}$ precipitation. In the third modification, enrichment was done directly after the addition of LiCl. Finally, and since good LMW RNA yields were still obtained by removing the various steps, the complete $\mathrm{LiCl}$ precipitation step was omitted in the fourth modification. LMW RNA enrichment was directly performed using the upper phase after the chloroform extraction (modification 4 in Figure 2), which, strikingly, worked very well for both plant species (Figure 3a and 3b).

The extractions were performed in triplicate and the LMW RNA extracts were electrophoresed using denaturing polyacrylamide gels (Figure 3 ). The presence of sRNAs obtained with the different strategies was observed. The final strategy (where the enrichment step was performed right after the chloroform extraction) showed a less intense band corresponding to $40 \mathrm{nt}$ RNAs and produced a cleaner extract compared to the other methods (Figure 3 and Table 2). Furthermore, spectrophotometric analysis showed that all the 260/280 ratios were high when using the different methods to extract LMW RNA from cactus tissue, indicating a good purity of the samples (Table 2). However, the 260/230 ratios were very low in all cases, both for cactus as for Arabidopsis. Nevertheless, LMW RNA analyzed in polyacrylamide gels showed well defined 5.8S, 5S, and tRNA bands, which suggests a good recovery (Figure 3 ). Moreover, a well defined 24 nt band (sRNAs) could be directly observed in the polyacrylamide gel. This band

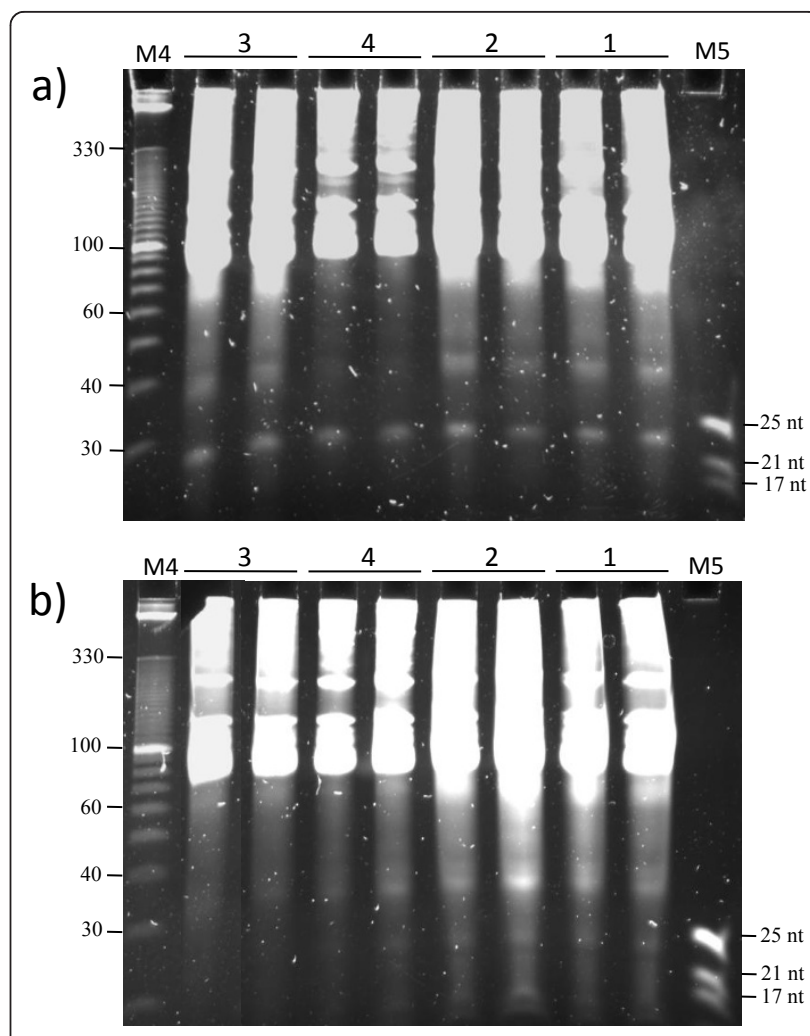

Figure 3 Analysis of small RNAs isolated from cactus and Arabidopsis. a) Gel electrophoresis of LMW RNA from cactus floral buds obtained with different modifications of the LiCl method, b) Gel electrophoresis of LMW RNA from Arabidopsis leaves obtained with various modifications of the $\mathrm{LiCl}$ method. Modification steps are indicated above each gel ( $a$ and b), namely 1) LMW RNA enrichment from the supernatants obtained after precipitation of total RNA, 2) LiCl precipitating, followed by LMW RNA enrichment, 3) Addition of LiCl, directly followed by LMW RNA enrichment, and 4) Enrichment of LMW RNA directly after the chloroform extraction without addition of LiCl. $0.1 \mathrm{~g}$ of tissue was used for each sample extraction (in triplicate). $2 \mu \mathrm{g}$ of each sample was loaded on a 12.5\% polyacrylamide gel (gel stained with SYBR gold). M4, 10 bp DNA Ladder (Invitrogen); M5, microRNA Marker (NEB).

was observed and well defined when using the different methods. Interestingly, the sRNAs isolated using modification 4 (where the $\mathrm{LiCl}$ precipitation step was omitted) showed less background in the gel and a higher concentration of LMW RNA, showing that this strategy is efficient for LMW RNA isolation from plant species with high polysaccharide content, leading to increased yield in a reduced number of steps using conventional lab chemicals. This method does not only allow efficient LMW RNA recovery from cactus or Arabidopsis, but it also works very well for other plant species, such as agave, banana, tomato, and tobacco (Figure 4a). Furthermore, when necessary, HMW RNA may still be recovered from the pellet after the polyethylene glycol precipitation (step 9 of the Small RNA extraction protocol; data not shown). 
Table 2 Concentrations* of LWM RNA samples obtained using the LiCl method with different modifications

\begin{tabular}{|c|c|c|c|c|c|}
\hline Tissue & Modification & $\mathrm{ng} / \mu \mathrm{l}$ & Average $260 / 280$ & Average $260 / 230$ & Yield $(\mu \mathrm{g})$ \\
\hline \multirow[t]{4}{*}{ Cactus } & $\begin{array}{l}\text { 1) LMW RNA enrichment from the supernatants obtained after } \\
\text { precipitation of total RNA }\end{array}$ & 382.30 & 1.82 & 1.81 & 7.65 \\
\hline & 2) LiCl precipitating (overnight), followed by LMW RNA enrichment & 527.75 & 1.81 & 1.90 & 10.56 \\
\hline & 3) Addition of LiCl, directly followed by LMW RNA enrichment & 291.42 & 1.66 & 1.35 & 5.83 \\
\hline & $\begin{array}{l}\text { 4) Enrichment of LMW RNA directly after the chloroform extraction } \\
\text { without addition of } \mathrm{LiCl}\end{array}$ & 1008.42 & 2.02 & 1.04 & 20.17 \\
\hline \multirow[t]{4}{*}{ Arabidopsis } & $\begin{array}{l}\text { 1) LMW RNA enrichment from the supernatants obtained after } \\
\text { precipitation of total RNA }\end{array}$ & 582.52 & 1.68 & 1.23 & 11.65 \\
\hline & 2) LiCl precipitating (overnight), followed by LMW RNA enrichment & 333.68 & 1.66 & 1.21 & 6.67 \\
\hline & 3) Addition of LiCl, directly followed by LMW RNA enrichment & 609.38 & 1.53 & 1.13 & 12.19 \\
\hline & $\begin{array}{l}\text { 4) Enrichment of LMW RNA directly after the chloroform extraction } \\
\text { without addition of LiCl }\end{array}$ & 1418.77 & 1.53 & 0.96 & 28.38 \\
\hline
\end{tabular}

*Yields and spectrophotometric A260/A230 and A260/A280 ratios of LMW RNA isolated with LiCl extraction method modifications from Prickly pear cactus and Arabidopsis. $0.1 \mathrm{~g}$ of tissue was used for the extraction and quantified using a Nanodrop spectrophotometer. LMW RNA was extracted two times in triplicate (6 independent samples).

\section{Northern blot analysis}

As described above, positive results were obtained for the isolation of LMW RNAs using the fourth modification and well defined sRNA bands could be visualized in a gel for 6 different plant species (Figure 4a). To test

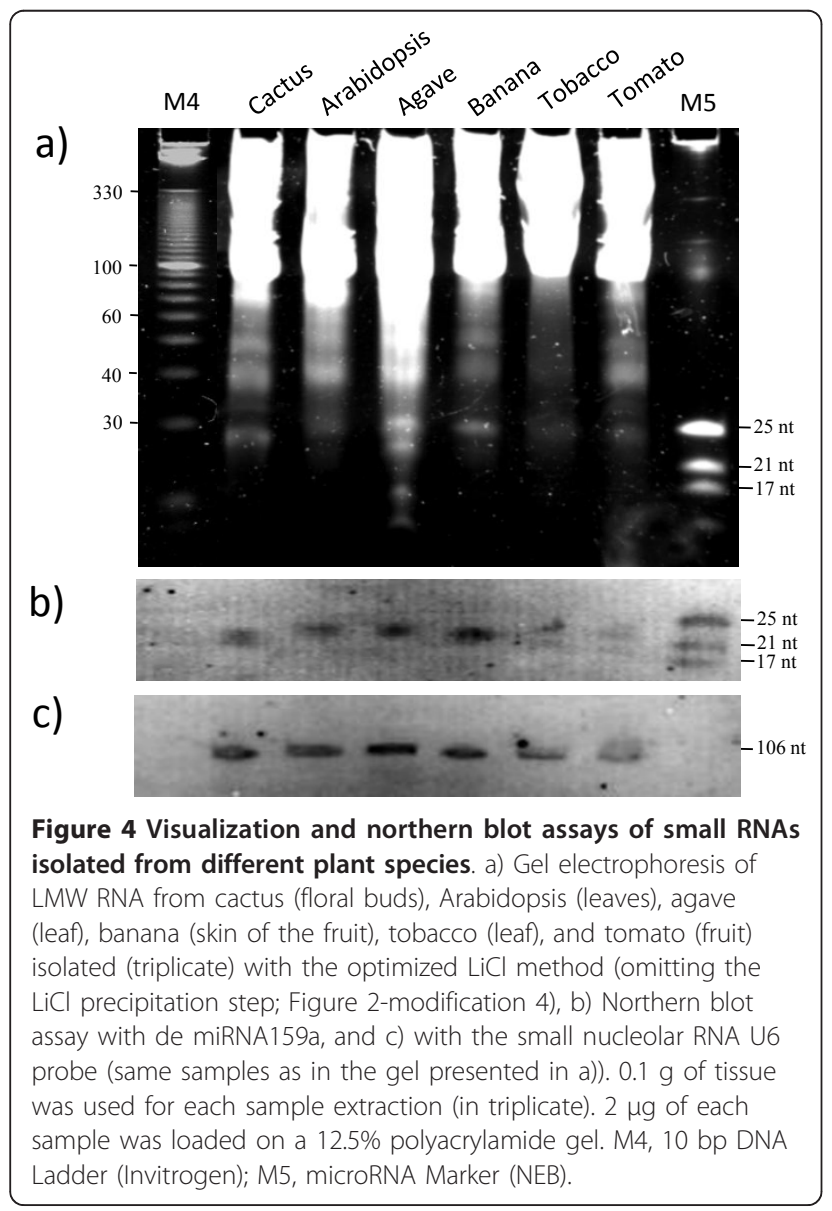

whether the LMW RNA observed in the gel represented intact molecules and not degradation products, a northern blot assay was performed. Figure $4 \mathrm{~b}$ and $4 \mathrm{c}$ shows that indeed, LMW RNA from cactus and Arabidopsis isolated with the shortest protocol version can be successfully detected in northern blot hybridization experiments using the miRNA159a probe, detecting 21 nt sRNA molecules, as well as using the small nucleolar RNA U6 probe, which detects 106 nt LMW RNA species (Figure $4 \mathrm{~b}$ and $4 \mathrm{c}$, respectively).

\section{Conclusion}

Here we provide a simple and effective method suitable for sRNA extraction from polysaccharide-rich material such as cactus, agave, banana, and tomato tissues, which also works well for less complex plant tissues form e.g., Arabidopsis and tobacco. This modified extraction method gives good yield and quality of LMW RNA species. Moreover, the LMW RNA obtained from the different plant species was successfully used for northern blot assays. Well defined bands were detected when using the miRNA159a and the small nucleolar RNA U6 probes. Therefore, the sRNA molecules that can be obtained with this low-cost short method are suitable for downstream assays like northern blot hybridization, and most likely also for cloning and sequencing of sRNAs.

\section{Acknowledgements}

We thank Dr. Candelario Mondragón-Jacobo at INIFAP Norte de Guanajuato for providing cactus material, Alba Ramos-Olmos for technical advice with northern blot assays, and two anonymous reviewers for their valuable comments. We also thank the Mexican Science Council (CONACyT) for PhD fellowships to FFRC (199450) and to NDF (159754). The work in de Folter laboratory is financed by CONACyT 82826.

\section{Author details}

'Laboratorio Nacional de Genómica para la Biodiversidad (LANGEBIO), CINVESTAV-IPN, Km. 9.6 Libramiento Norte, Carretera Irapuato-León, CP 


\section{Authors' contributions}

FFRC did the major experimental work. NDF and JPVC contributed to the northern blot assays and with technical advice. FFRC, ACH, NMM, and SDF conceived the project and designed the experiments. FFRC, NMM, and SDF drafted the manuscript. All authors read and approved the final manuscript.

\section{Competing interests}

The authors declare that they have no competing interests.

Received: 28 October 2010 Accepted: 24 February 2011

Published: 24 February 2011

\section{References}

1. Carthew RW, Sontheimer EJ: Origins and Mechanisms of miRNAs and siRNAs. Cell 2009, 136:642-655.

2. Chen X: Small RNAs and their roles in plant development. Annu Rev Cell Dev Biol 2009, 25:21-44.

3. Chen X: Small RNAs - secrets and surprises of the genome. Plant J 2010, 61:941-958.

4. Voinnet O: Origin, biogenesis, and activity of plant microRNAs. Cell 2009, 136:669-687.

5. Chen D, Meng Y, Ma X, Mao C, Bai Y, Cao J, Gu H, Wu P, Chen M: Small RNAs in angiosperms: sequence characteristics, distribution and generation. Bioinformatics 2010, 26:1391-1394.

6. Lu C, Tej SS, Luo S, Haudenschild CD, Meyers BC, Green PJ: Elucidation of the Small RNA Component of the Transcriptome. Science 2005, 309:1567-1569.

7. Carra A, Gambino G, Schubert A: A cetyltrimethylammonium bromidebased method to extract low-molecular-weight RNA from polysaccharide-rich plant tissues. Anal Biochem 2007, 360:318-320.

8. Carra A, Mica E, Gambino G, Pindo M, Moser C, Pe ME, Schubert A: Cloning and characterization of small non-coding RNAs from grape. Plant J 2009, 59:750-763.

9. Pilcher RL, Moxon S, Pakseresht N, Moulton V, Manning K, Seymour G, Dalmay T: Identification of novel small RNAs in tomato (Solanum lycopersicum). Planta 2007, 226:709-717.

10. Chappell L, Baulcombe D, Molnár A: Isolation and Cloning of Small RNAs from Virus-Infected Plants. Current Protocols in Microbiology 2005, UNIT 16H.2.

11. Meyers BC, Green PJ: Plant MicroRNAs - Methods and Protocols. Humana Press; 2009.

12. Moxon S, Jing R, Szittya G, Schwach F, Rusholme Pilcher RL, Moulton V, Dalmay T: Deep sequencing of tomato short RNAs identifies microRNAs targeting genes involved in fruit ripening. Genome Res 2008, 18:1602-1609.

13. Itaya A, Bundschuh R, Archual AJ, Joung JG, Fei Z, Dai X, Zhao PX, Tang Y, Nelson RS, Ding B: Small RNAs in tomato fruit and leaf development. Biochim Biophys Acta 2008, 1779:99-107.

14. Hutvagner G, Mlynarova L, Nap JP: Detailed characterization of the posttranscriptional gene-silencing-related small RNA in a GUS genesilenced tobacco. RNA 2000, 6:1445-1454.

15. Chomczynski P, Sacchi N: Single-step method of RNA isolation by acid guanidinium thiocyanate-phenol-chloroform extraction. Anal Biochem 1987, 162:156-159

16. Chomczynski P, Sacchi N: The single-step method of RNA isolation by acid guanidinium thiocyanate-phenol-chloroform extraction: twentysomething years on. Nat Protoc 2006, 1:581-585.

17. Pall GS, Hamilton AJ: Improved northern blot method for enhanced detection of small RNA. Nat Protoc 2008, 3:1077-1084

18. Verwoerd TC, Dekker BM, Hoekema A: A small-scale procedure for the rapid isolation of plant RNAs. Nucleic Acids Res 1989, 17:2362.

doi:10.1186/1746-4811-7-4

Cite this article as: Rosas-Cárdenas et al: A simple and efficient method for isolating small RNAs from different plant species. Plant Methods 2011 7:4.

\section{Submit your next manuscript to BioMed Central and take full advantage of:}

- Convenient online submission

- Thorough peer review

- No space constraints or color figure charges

- Immediate publication on acceptance

- Inclusion in PubMed, CAS, Scopus and Google Scholar

- Research which is freely available for redistribution

Submit your manuscript at www.biomedcentral.com/submit
Biomed Central 